\title{
Legal Challenges in Government Imposition of Water Conservation: The Kansas Example
}

\author{
John C. Peck*
}

\begin{abstract}
This article deals with legal challenges in conserving water in the United States, using Kansas as an example. The focus is on one aspect of American water allocation law - the extent to which a state can force reductions in pumping by holders of water rights. It explains the hybrid nature of water rights, which on the one hand are "real property rights," and yet on the other hand they are viewed as rights only to use water and not to own the water itself. Because they are a kind of property right, they are protected by the fifth amendment to the U.S. Constitution against "takings" by the government without compensation. The question becomes: to what extent, then, can states demand reductions in pumping without having to pay compensation? The answer is difficult for both water right holders and government officials to predict. The law of groundwater rights in Kansas illustrates the problem. The article describes the Kansas law in the context of other states on this issue, including the historic changes in Kansas' water law doctrines, water management under the appropriation doctrine, the public trust doctrine, groundwater management districts, and intensive groundwater use control areas, as well as recent attempts to foster voluntary actions by water right holders that avoid government imposition of restrictions. Questions remain in Kansas and elsewhere about where the line can be drawn, between acceptable government restrictions and unacceptable takings of property. Future drought caused by climate change will focus even more attention on this question.
\end{abstract}

To some extent, having security in water means having sufficient supplies of fresh water when and where a country or a state needs it. One method of ensuring water supplies is not to waste it, that is, to use it as efficiently as possible. Technical innovations continue to improve our methods of diverting and using water efficiently. ${ }^{1}$ Government policies could also be changed to promote water conservation rather than water use. "Conservation" is conventionally defined as "careful preservation... of a natural resource to prevent... destruction” (Webster's New Collegiate Dictionary, 1981). For this article, I define conservation as "government regulatory actions requiring a reduction of pumping by water right holders."

\footnotetext{
${ }^{1}$ For example, changing from flood to center pivot irrigation; retrofitting center pivots with drop nozzles; moving to drip irrigation; lining ditches; repairing leaking pipes; changing price structures for public water supplies; and utilizing remote sensing controls for irrigation scheduling, to name a few. ${ }^{2}$ These include, among others, reducing or eliminating farm subsidies for water-intensive crops, eliminating the "use it or lose it" aspect of the Prior Appropriation Doctrine (discussed below), weakening statutes that protect private property rights against government regulation, requiring metering of water use, and imposing best-practices conservation measures.
}

Connell Teaching Professor of Law, Univ. of Kansas School of Law, Lawrence KS 66045; Special Counsel, Foulston Siefkin LLP, Overland Park, KS 66210. Received 3 Feb. 2014. *Corresponding author (jpeck@ku.edu).

Published in Agron. J. 106:1-6 (2014)

doi:10.2134/agronj14.0058

Available freely online through the author-supported open access option. Copyright $\odot 2014$ by the American Society of Agronomy, 5585 Guilford Road, Madison, WI 53711. All rights reserved. No part of this periodical may be reproduced or transmitted in any form or by any means, electronic or mechanical, including photocopying, recording, or any information storage and retrieval system, without permission in writing from the publisher.
Instead of focusing on technical methods or changes in government policy to conserve water, this article deals with the law and on one aspect of the American system of water allocation law that presents hurdles to conserving water for use by future generations-the question of the extent to which a state can force reductions in pumping by holders of water rights for the purpose of conserving water for the present and the future. The article begins by providing some information on basic concepts (water and water rights as property rights) and by distinguishing water allocation law from water quality law. Then, brief descriptions are given of the two general water allocation regimes for surface water and the several groundwater doctrines found in the United States. It states the origin of the challenge to conserving-constitutional protections of private property-and describes how some states have dealt with the challenge. Finally, it uses Kansas law in this context of American water allocation law as an example of how law is evolving in attempting to meet the problems of conservation.

Located in the center of the United States at the boundary between the wet eastern states and the arid western states, with neither mountain streams nor coastal waters, Kansas fairly represents some issues faced by other states in water allocation and conservation. Annual precipitation ranges from over $101.6 \mathrm{~cm}$ (40 in.) in southeastern Kansas to about $40.64 \mathrm{~cm}$ (16 in.) in western Kansas. Rivers generally run eastward and southward to serve the more populous parts of the state. In the dryer,

Abbreviations: DWR, Division of Water Resources; GMDs, groundwater management districts; IGUCAs, intensive groundwater use control areas; LEMAs, local enhanced management areas. 
western part of the state, the multi-state High Plains Aquifer provides large but diminishing supplies of ground water to serve small towns and a thriving crop and cattle industry.

\section{SOME BASICS}

Water, Water Rights, and Property. In general American law distinguishes "water" from "water rights." Water is a liquid, $\mathrm{H}_{2} \mathrm{O}$, is movable, and is "personal property" like a desk or a car. A water right is a right to divert water for a period of time, generally forever (as long as the supply lasts), from a specific source of water to be used on a specific parcel of land. It is generally considered to be "real property" or "real estate," is generally deemed to be appurtenant to the land where used, ${ }^{3}$ and is transferred using deeds and financed using mortgages. States differ, however, in their treatment of water rights as property rights. Water rights are often seen as fundamentally different from other real property. They are a "hybrid" property right because the water resource is often described as a public resource owned or controlled by the state, and water rights are "usufructuary" in character (Williams v. City of Wichita, 1962; Getches. 2009), that is, a right to use the water, not to own the molecules. Moreover, the "public interest" or the "public welfare" is often used as a backdrop standard in a state's determination of whether to grant a water right or to permit changes in existing water rights.

U.S. Water Allocation Law in General. Water allocation law is distinguished from water quality law, which is generally classified as part of environmental law, which is largely based on federal law. ${ }^{4}$ Water allocation law is mostly created and administered at the state level, with some federal influence. Sometimes the two bodies of law can intersect. ${ }^{5}$ The subject of this article is generally outside the subject matter and scope of environmental law or water quality law.

For the law of surface water allocation, the United States can be divided into two sections, the humid East and the arid West, the boundary running along the eastern boundaries of the Dakotas south along Nebraska, Kansas, and Oklahoma to Texas. Eastern states in general employ the "Riparian Doctrine," under which the owners of land riparian to rivers are deemed to have water rights by virtue of the land ownership. Water use is not required to maintain the right, and disputes are resolved in court on a sharing basis. Some eastern states have also required permits, often aimed at environmental protection, for certain uses such as dam building (Grant and Weber, 2010, p. 305-306). Recently some states like Florida have legislated comprehensive permit systems, sometimes called "regulated riparianism," that require the obtaining of permits before diverting water for some uses (Grant and Weber, 2010,

\footnotetext{
${ }^{3}$ Exceptions include Colorado ("Water rights in Colorado are not generally appurtenant to land.") (Schroeder, 2014) and New Mexico ("[A]all waters appropriated for irrigation purposes... shall be appurtenant to specified lands"-other types of water rights are not mentioned) (JUSTIA US Law, 2013, New Mexico Statutes, N.M.S. \$72-1-2).

${ }^{4}$ Much of water quality law is derived from the federal Clean Water Act and other legislation enforced by the U.S. Environmental Protection Agency (EPA), although EPA often partners with state agencies to administer these laws.

${ }^{5}$ For example, a water right could be impaired when a neighboring upstream water user releases poor quality water that adversely affects the quality of the water of a downstream water right holder. Another example would be federal Endangered Species Act requirements and effects that result in a water user having to cut back diversion quantities.
}

p. 308-309). The law for rivers in the western states is the "Prior Appropriation Doctrine," "first in time, first in right," under which water users obtain water appropriation rights entitling them to divert and use water for beneficial purposes for as long as supplies are available. Disputes are settled by allowing the earliest or senior user the full extent of its right, with junior users receiving either less water or no water in times of shortage. Appropriation rights must be used or the state declares them abandoned. The permits given in eastern states differ from the water appropriation rights in the West: in the East, priority is not a factor; eastern permits have a set term of years; and these permits are subject to more administrative discretion in times of water shortage and may be reallocated to other uses (Grant and Weber, 2010, p. 308-309).

Groundwater law is more diverse. Groundwater allocation doctrines vary from "absolute ownership" (surface owner owns ground water beneath) (Texas), to "reasonable use" (surface owner can pump all it needs, but must be for a reasonable use on its land), to "correlative rights" (surface owners share the ground water beneath, akin to Riparian Doctrine for rivers) (California), to "prior appropriation" (most western states), and to the Restatement $2 \mathrm{~d}$ of Torts (a combination of correlative rights and reasonable use) (Wisconsin). To slow the depletion of aquifers, some states have enabled the creation of special groundwater districts to allow local management, ${ }^{6}$ or have designated groundwater basins or areas inside of which management differs from other areas of the state, ${ }^{7}$ Some states have judicial decisions that have curtailed pumping on the basis of seniority in well-defined groundwater aquifers with the goal of stopping groundwater mining. ${ }^{8}$

Table 1 summarizes the law of surface water and ground water in the 50 U.S. states. Readers are cautioned that the water allocation laws of many states, particularly in the east, are difficult to classify neatly and precisely. For more definition, consult the various state summary chapters in Waters and Water Rights shown in the references.

Constitutional Protections of Property Rights. The fifth Amendment to the U.S. Constitution protects private property against government "takings," which includes both direct takings by eminent domain and indirect takings by government regulations that greatly reduce or totally eliminate the value of the property. Because water rights are property rights, water rights are subject to this protection. However, because water is a public resource and a hybrid property right, and because of the evolving nature of how water and water rights are viewed by the public, legislatures, and courts, it is difficult to know and predict how much protection water rights have against state regulation.

\footnotetext{
${ }^{6}$ For example, Kansas (Kansas Statutes. Kansas Legislature, 2013-2014, K.S.A. 82a-1021, et seq.); Colorado (Colorado Legal Resources, Colorado Revised Statutes, 2014, C.R.S. 37-90-118, et seq.). Some districts belong to associations (e.g., Groundwater Management District Association [Thompson and Angel, 2014, GMDA Homepage], which includes the following state members: Colorado, Kansas, Louisiana, Mississippi, Nebraska, Oklahoma, and Texas).

${ }^{7}$ For example, Idaho (State of Idaho Legislature, 2014, Idaho Statutes. I.S. 42-233a ["critical ground water area"] and 42-233b ["groundwater management area”]); Colorado (Colorado Legal Resources, 2014, Colorado Revised Statutes, 2014. C.R.S. 27-90-106); Fundingsland v. Colo. Ground Water Commission (1970); and Texas (Texas Water Code, 2014. TRC \$35.001).

${ }^{8}$ See, for example, Baker v. Ora-Ida Foods, Inc. (1973).
} 


\begin{tabular}{|c|c|c|c|c|c|c|c|c|c|}
\hline \multirow[b]{2}{*}{ State } & \multicolumn{3}{|c|}{ Surface water } & \multicolumn{5}{|c|}{ Ground water } & \multirow[b]{2}{*}{ Notes } \\
\hline & $\mathrm{RD} \dagger$ & RR & PAD & $\mathrm{AO}$ & $\mathrm{RU}$ & $\mathrm{CR}$ & PAD & $\mathrm{R} 2 \mathrm{dT}$ & \\
\hline Alabama & $x$ & & & & $x$ & & & & $\begin{array}{l}\text { High volume users must } \\
\text { apply for Certificates of Use } \\
\text { for analysis purposes (not } \\
\text { as permits); much litigation } \\
\text { between Alabama, Florida, and } \\
\text { Georgia }\end{array}$ \\
\hline Alaska & & & $x$ & & & & $x$ & & \\
\hline Arizona & & & $x$ & & $x$ & & & & $\begin{array}{l}\text { Groundwater Code abolishes } \\
\text { reasonable use within Active } \\
\text { Management Areas }\end{array}$ \\
\hline Arkansas & $x$ & & & & $x$ & & & & \\
\hline California & $x$ & & $x$ & & & $x$ & & & $\begin{array}{l}\text { Ground water: unregulated } \\
\text { at state level, except for } \\
\text { "subterranean streams flowing } \\
\text { through known and definite } \\
\text { channels," which are regulated } \\
\text { like surface water }\end{array}$ \\
\hline Colorado & & & $x$ & & & & $x$ & & $\begin{array}{l}\text { "Designated ground water" } \\
\text { administered separately from } \\
\text { tributary ground water and } \\
\text { surface water;"nontributary } \\
\text { ground water" not subject to } \\
\text { prior appropriation }\end{array}$ \\
\hline Connecticut & & $x$ & & & $x$ & & & & $\begin{array}{l}\text { Regulated riparianism as of } \\
\text { I982; no mention of ground } \\
\text { water in Connecticut state } \\
\text { survey }\end{array}$ \\
\hline Delaware & $x$ & & & & $x$ & & & & \\
\hline Florida & & $x$ & & & & & & & $\begin{array}{l}\text { Five water management } \\
\text { districts; users must acquire } \\
\text { consumptive use permits; } \\
\text { ground and surface water } \\
\text { regulated identically, but } \\
\text { surface water use prioritized } \\
\text { over groundwater use }\end{array}$ \\
\hline Georgia & $x$ & & & & $x$ & & & & \\
\hline Hawaii & & $x$ & & & & $x$ & & & \\
\hline Idaho & & & $x$ & & & & $x$ & & \\
\hline Illinois & $x$ & & & & $x$ & & & & \\
\hline Indiana & & $x$ & & $x$ & & & & & $\begin{array}{l}\text { Emergency Groundwater } \\
\text { Rights Act provides relief to } \\
\text { the groundwater user whose } \\
\text { water supply is damaged by } \\
\text { high-volume users }\end{array}$ \\
\hline lowa & & $x$ & & & & & & & \\
\hline Kansas & & & $x$ & & & & $x$ & & \\
\hline Kentucky & & $x$ & & & $x$ & & & & \\
\hline Louisiana & $x$ & & & $x$ & & & & & \\
\hline Maine & $x$ & & & $x$ & & & & & $\begin{array}{l}\text { "ostensibly... absolute } \\
\text { dominion rule" but modified } \\
\text { by supreme judicial court and } \\
\text { legislation (Rayback and Taylor, } \\
2013 \text { ) }\end{array}$ \\
\hline Maryland & & & & & & & & & $\begin{array}{l}\text { Regulated Riparianism; prior } \\
\text { permits required; domestic } \\
\text { and municipal uses have } \\
\text { priority }\end{array}$ \\
\hline Massachusetts & & $x$ & & $x$ & & & & & $\begin{array}{l}\text { Ground water: absolute } \\
\text { ownership, but with qualifi- } \\
\text { cation and exceptions and } \\
\text { potentially moving toward } \\
\text { reasonable use }\end{array}$ \\
\hline Michigan & $x$ & & & & $x$ & & & & \\
\hline Minnesota & & $x$ & & & $x$ & & & & \\
\hline Mississippi & & & & & & & & & $\begin{array}{l}\text { Regulated Riparianism since } \\
\text { I985 }\end{array}$ \\
\hline
\end{tabular}




\begin{tabular}{|c|c|c|c|c|c|c|c|c|c|}
\hline \multirow[b]{2}{*}{ State } & \multicolumn{3}{|c|}{ Surface water } & \multicolumn{5}{|c|}{ Ground water } & \multirow[b]{2}{*}{ Notes } \\
\hline & $\mathrm{RD} \dagger$ & RR & PAD & $\mathrm{AO}$ & RU & $\mathrm{CR}$ & PAD & R2dT & \\
\hline Missouri & $x$ & & & & $x$ & & & & \\
\hline Montana & & & $x$ & & & & $x$ & & \\
\hline Nevada & & & $x$ & & & & $x$ & & \\
\hline New Jersey & $x$ & & & & $x$ & $x$ & & & $\begin{array}{l}\text { For ground water: correlative } \\
\text { rights are primary, but a } \\
\text { violation of correlative rights } \\
\text { not actionable unless it was } \\
\text { also unreasonable }\end{array}$ \\
\hline New Mexico & & & $x$ & & & & $x$ & & \\
\hline North Dakota & & & $x$ & & & & $x$ & & \\
\hline Ohio & $x$ & & & & $x$ & & & & \\
\hline Oklahoma & $x$ & & $x$ & & $x$ & $x$ & & & $\begin{array}{l}\text { Stream waters not appropri- } \\
\text { ated by riparian owners are } \\
\text { available for appropriation } \\
\text { through permits; ground water } \\
\text { appears to be allocated on } \\
\text { the basis of a combination of } \\
\text { reasonable use and correlative } \\
\text { rights }\end{array}$ \\
\hline Oregon & & & $x$ & & & & $x$ & & \\
\hline Pennsylvania & $x$ & & & & $x$ & & & & \\
\hline Utah & & & $\mathrm{x}$ & & & & $x$ & & \\
\hline Vermont & $x$ & & & & $x$ & $x$ & & & $\begin{array}{l}\text { Vermont has declared ground } \\
\text { water a public trust resource }\end{array}$ \\
\hline Virginia & & $x$ & & $x$ & $x$ & & & & $\begin{array}{l}\text { For ground water:Virginia } \\
\text { courts have not clarified } \\
\text { whether Virginia is an absolute } \\
\text { ownership or reasonable use } \\
\text { state }\end{array}$ \\
\hline Washington & & & $\mathrm{x}$ & & & & $x$ & & $\begin{array}{l}\text { Riparian owners have a right } \\
\text { to have water flow to their } \\
\text { lands, actionable against } \\
\text { permitted appropriators. }\end{array}$ \\
\hline West Virginia & $x$ & & & & $x$ & $x$ & & & $\begin{array}{l}\text { For ground water: correlative } \\
\text { rights are primary, but a } \\
\text { violation of correlative rights } \\
\text { not actionable unless it was } \\
\text { also unreasonable }\end{array}$ \\
\hline Wisconsin & & $x$ & & & & & & $x$ & \\
\hline Wyoming & & & $x$ & & & & $x$ & & \\
\hline
\end{tabular}

$\dagger$ Abbreviations: AO, Absolute Ownership; CR, Correlative Rights; PAD, Prior Appropriation Doctrine; R2dT, Restatement 2d of Torts; RD, Riparian Doctrine; RR, Regulated Riparianism; RU, Reasonable Use. 


\section{JUDICIAL PROTECTION OF WATER RIGHTS AGAINST TAKINGS}

Being property rights, presumably water rights are protected against overly strong government regulations, regulations that go too far. Old cases such as Enterprise Irrigation Dist. v. Willis (1939) (taking found when the government required irrigator to reduce annual pumping from 99.06 to $91.44 \mathrm{~cm} \mathrm{[39}$ to 36 in.]) and more recent ones like Tulare Lake Basin Water Storage Dist. v. U.S. (2001) (taking found when reductions were ordered to comply with the Endangered Species Act) show strong judicial protection of water rights.

Judicial exceptions to this principle, however, can be found as well. For example, states are allowed to change their overall water rights doctrines to the detriment of water right holders who before the change were not actually using their water rights. ${ }^{9}$ And a California case has held that reductions in water diversions may be required if the water right holder is wasting water (Imperial Irrigation Dist. v State Water Res. Control Bd., 1990).

A significant step in the direction of preserving water for the future in one state occurred in 1983 with the California Supreme Court decision in Nat. Audubon Soc. v. Sup. Ct. (1983), in which the court applied the "Public Trust Doctrine" to water rights. That doctrine holds that navigable waters are held by the state in trust and cannot be granted absolutely for private ownership. Los Angeles had obtained water rights several decades before out of fresh water tributaries running into Mono Lake, a saline lake located several hundred miles away. Pumping had reduced the lake level, causing serious, negative environmental effects. The court held that the Prior Appropriation Doctrine and the Public Trust Doctrine must be read together. Pumping under prior appropriation water rights could thus be reconsidered and reduced based on current knowledge and needs. New Mexico, while not adopting the Public Trust Doctrine, has used the public welfare as a factor in appropriating and transferring water rights. ${ }^{10}$

\section{THE KANSAS EXAMPLE}

Kansas Water Allocation Law. Once a riparian doctrine state for surface water and an absolute ownership state for ground water, Kansas adopted prior appropriation for both surface water and ground water in 1945 with the enactment of the Kansas Water Appropriation Act. (Kansas Statutes. Kansas Legislature, 2013-2014, K.S.A. 82a-701 et seq.) Kansas law exemplifies the hybrid, quasi-public nature of a water right noted above: on the one hand the Kansas Water Appropriation Act expressly states that a water right is "a real property right appurtenant to... the land... in connection with which the water is used...”; but it also states that "all water within the state... is hereby dedicated to the use of the people of the state, subject to the control and regulation of the state..." and that a water appropriation "shall not constitute ownership of such water.” (Kansas Statutes. Kansas Legislature, 2013-2014. K.S.A. 82a-701[g], -702 and -707[a]) When Kansas changed from the common law doctrines in 1945 to prior appropriation, it declared unused surface water and groundwater rights to be lost. The Kansas Supreme Court upheld this action in

\footnotetext{
${ }^{9}$ See, for example, New Mexico (State ex rel. Bliss v. Dority, 1950) and Kansas (Williams v. City of Wichita, 1962).

${ }^{10} \mathrm{New}$ Mexico "has legislated, and courts have recognized, that the public welfare is a factor in appropriating water and transferring water rights." (De Young, 2009).
}

1962, holding that the Act did not constitute an unconstitutional taking of property. (Williams v. City of Wichita, 1962) The 1991 legislature amended the Appropriation Act to empower the Division of Water Resources (DWR) to require holders of water rights to adopt conservation plans. (Kansas Statutes. Kansas Legislature, 2013-2014. vol. 6A, K.S.A. 82a-733) Yet, in 1991 when the Kansas Supreme Court was asked to adopt and apply the Public Trust Doctrine, it refused to do so (Meek v. Hays, 1990). ${ }^{11}$ In 1995, the Kansas legislature enacted the Private Property Protection Act (Kansas Statutes. Kansas Legislature, 2013-2014, K.S.A. 77-701 et seq.), which while not directed expressly to water rights may be relevant to future attempts to curtail pumping. With an express purpose of reducing the "risk of undue or inadvertent burdens on private property rights resulting from lawful government actions" (Kansas Statutes. Kansas Legislature, 2013-2014, K.S.A. 77-702) the act requires governmental agencies before "any governmental action is initiated" to prepare reports that follow guidelines that provide for alternatives to the action that may "reduce the extent of limitation of the use of the private property" and that may "reduce the risk to the state that the action will be deemed a taking" (Kansas Statutes. Kansas Legislature, 2013-2014, K.S.A. 77-706).

Evolution of Kansas Groundwater Law and Management. The enactment of the 1945 Water Appropriation and the onset of high-capacity, center-pivot irrigation saw huge numbers of irrigation water permit applications in the 1950s and 1960s. These developments led to an evolving attempt by the legislature, the DWR, and others to manage ground water and curtail pumping.

In 1972, recognizing that groundwater aquifers were being "mined" (withdrawals exceeding recharge), Kansas enacted legislation enabling the creation of "groundwater management districts" (GMDs), to allow a degree of local control of groundwater management, but while keeping basic water law intact. (Kansas Statutes. Kansas Legislature, 2013-2014. K.S.A. 82a-1021 et seq.). Five GMDs formed. In 1978, the legislature added “intensive groundwater use control areas" (IGUCAs) as another method of protecting ground water in smaller, localized problem areas. If an IGUCA is established, the chief engineer (the DWR agency head) has extraordinary powers and remedies, including ordering pumping restrictions that do not follow strict time priority.

In 1992, following a public hearing with many stakeholder parties represented by legal counsel, the chief engineer ordered the establishment of the Walnut Creek IGUCA, to protect the senior surface water rights used to supply the Cheyenne Bottoms wetland, one of the most important migratory bird stopover points in America. The order required annual pumping reductions of almost all of the 800 or so irrigation systems upstream that were pumping from the creek's alluvium. The order created two groups, with 1 Oct.1965, as the dividing priority date: the group of "senior" appropriators was ordered to reduce pumping from 22 to $25 \%$ on the basis of waste; the "junior" group was ordered to reduce pumping from 65 to $71 \%$ to achieve "safe yield" in the basin-that is, to eliminate mining. Thus, the order did not strictly enforce priority on an individual basis, but instead amounted to a kind of "mass allocation." The significance of the case was that seniority of priority date, which while generally followed in the

\footnotetext{
${ }^{11}$ The case involved ownership of the beds of a non-navigable streams and rights of the public to use the streams; thus, the case differed from the National Audubon case, which involved water rights.
} 
two groupings, was not the critical matter. The main outcome of the case was that some junior water rights were treated better as a group than some other junior rights. The losers in the case were the senior-most water rights in the junior group, because holders of those rights would ordinarily have expected the even more junior rights to be shut down entirely to create the safe yield sought in the basin. Interestingly, the entire group of irrigators, both those in the senior group and those in the junior group, filed an appeal in court from the chief engineer's administrative order, arguing that the statute and the order amounted to an unconstitutional taking of a property right. These irrigators, however, ultimately dismissed their appeal, so the question whether the statute and the order were constitutional was left unanswered.

The Walnut Creek IGUCA Order seemed to be the "writing on the wall" for other water right holders in western Kansas, which has led to some voluntary actions. In the mid-1990s, four entities (the U.S. Fish and Wildlife Service, the State of Kansas, Big Bend GMD No. 5, and a group of irrigators) in the Rattlesnake Creek Basin, located Southeast of the Walnut Creek Basin, signed an agreement that called for reduced pumping in the basin and the establishment of a water bank. In 2012, the Kansas legislature passed a bill that permits establishing "local enhanced management areas" (LEMAs). (Kansas Statutes Annotated, 2013, K.S.A. 82a-1041) Irrigators and other water right holders can band together voluntarily to form a LEMA and to propose pumping restrictions on all users within the proposed boundaries. If approved by the chief engineer, the LEMA would act similarly to an IGUCA and would thus reduce long-term pumping to protect the life of the aquifer-all on a voluntary basis. Water users in one small area recommended formation of a LEMA, and the chief engineer approved its formation in late 2012.

Questions remain, however, about the constitutionality of imposing restrictions on existing water right holders in Kansas. In the Walnut Creek IGUCA case, many irrigators were required to make significant reductions in their permitapproved and historic pumping levels. A similar question may arise in the case of a LEMA order to reduce pumping by the irrigators within the LEMA boundaries, because a recalcitrant irrigator who refuses to accede to the establishment of the LEMA and its pumping restrictions might claim that this "taking" would require compensation if the irrigator were required to reduce pumping.

\section{SUMMARY AND CONCLUSIONS}

Viewing water rights as property rights helps protect economic values and investment-backed investments and expectations. After all, buyers will not purchase water rights, and lenders will not lend purchase money for water rights, unless the water rights enjoy the same protection enjoyed by other types of property. But, such a view makes it difficult for governments to conserve water, that is, to restrict pumping with the view toward protecting the supplies for future use. Thus, some groundwater aquifers are at risk for being depleted in the future unless courts, legislatures, or administrative agencies can create constitutionallypermissible exceptions to strict property concepts, such as the recognition of Public Trust Doctrine (California), or judicial or administrative imposition of mass pumping restrictions (Kansas), or use of the public interest generally or the public ownership of water as the basis for ordering pumping restrictions. Alternatively, voluntary restrictive measures by water right holders themselves could help ensure water security, and perhaps these water users will do this for philosophical reasons grounded in inter-generational equity considerations.

Kansas law illustrates these difficulties. On the one hand, statutes expressly declare water rights to be property rights and seek to protect private property from government actions that might curtail them, and the Kansas Supreme Court has refused to adopt the public trust doctrine. On the other hand, the Water Appropriation Act cut off unused water rights in 1945, and the Kansas Supreme Court upheld that action. The Act expressly states that water is dedicated to the use of the public and that water rights do not constitute ownership of water. Moreover, the legislature has empowered DWR to force water right holders to adopt conservation plans and to create IGUCAs inside of which the chief engineer can regulate pumping outside the usual rules of seniority. So, holders of water rights question the long-term security of those rights, while at the same time administrators question their powers to protect the water resource in the future. Future drought caused by climate change will likely focus even more attention on water conservation and will perhaps lead to some answers to these questions in Kansas.

\section{ACKNOWLEDGMENTS}

My thanks to Miriam Friesen, JD, University of Kansas School of Law, May 2014, for the excellent legal research she provided.

\section{REFERENCES}

Baker v. Ora-Ida Foods, Inc. 1973. 513 P.2d 627 (Ida. 1973).

Colorado Legal Resources. 2014, Colorado revised statutes. Lexis/Nexis, Official Publ. of the Colorado Revised Statutes. www.lexisnexis.com/hottopics/colorado/ (accessed 30 May 2014).

De Young, T.J. 2009. Waters and water rights. Vol. 4. II, State surveys, New Mexico. Matthew Bender and Company, Inc., New Providence, NJ.p. 2.

Enterprise Irrigation Dist. v. Willis. 1939.284 N.W.386 (Neb. 1939).

Fundingsland v. Colo. Ground Water Commission. 1970. 468 P.2d 835 (Colo. 1970).

Getches, D.H. 2009. Water law in a nutshell. 4th ed. Thomson/Reuters, St. Paul, MN. p. 86.

Grant, D.L., and G.S. Weber. 2010. Cases and materials on water law. 8th ed. Thompson/Reuters, St. Paul, MN.

Imperial. Irrigation Dist. v. State Water Res. Control Bd. 1990. 225 Cal. App. 3d 548

JUSTIA US Law. 2013. New Mexico statutes. Justia Co., Maountain View, CA. http:// law.justia.com/codes/new-mexico/2013/chapter-72/article-1/section-72-1-2/ (accessed 30 May 2014).

Kansas Statutes. Kansas Legislature. 2013-2014. Vol. 6-6A. Office of Revisor of Statutes of Kansas, Topeka. www.kslegislature.org/li/b2013_14/ statute/082a_000_0000_chapter/(accessed 30 May 2014).

Meek v. Hays. 1990.785 P.2d 1356 (Kan. 1990).

Nat. Audubon Soc. v. Sup. Ct. 1983.658 P.2d 709 (Cal. 1983).

Rayback, B.M., and W. Tayler. 2013. Waters and water rights. Vol.4. IV, State surveys, Maine. Matthew Bender and Company, Inc., New Providence, NJ. p. 5.

Schroeder, W.B. 2014. Waters and water rights. Vol. 4. State surveys, Colorado, §I(A) (v). Matthew Bender and Company, Inc., New Providence, NJ. p. 7.

State ex rel. Bliss v. Dority. 1950.225 P. 2 d 1007 (N.M. 1950).

State of Idaho Legislature. 2014, Idaho statutes. State of Idaho Legislature. http://legislature.idaho.gov/idstat/Title42/T42CH2.htm (accessed 30 May 2014).

Texas Water Code. 2014. Title2. Water administration. Subtitle E. Groundwater Management. ch. 35. Groundwater studies. \$35.001. Texas State Legislature. www. statutes.legis.state.tx.us/Docs/WA/htm/WA.35.htm (accessed 30 June 2014).

Thompson, T., and L. Angel. 2014. GMDA Homepage, Member States. Groundwater Manage. Districts Assoc. https://sites.google.com/a/lpnnrd.org/gmda/ (accessed 30 May 2014).

Tulare Lake Basin Water Storage Dist. v. U.S. 2001. 49 Fed. Cl. 313 (U.S. Ct. of Cl. 2001).

Waters and Water Rights. 2014.3d ed., Amy K. Kelley, Editor-in-Chief. Vol.4, Subpart B. State surveys. Matthew Bender and Company, Inc., New Providence, NJ.

Webster's New Collegiate Dictionary. 1981. G. \& C. Merriam Co., Springfield, MA. p. 239.

Williams v. City of Wichita. 1962.374 P.2d 578. 